\title{
Tyzzer 病に関する研究
}

\author{
藤 原 公 策 \\ 東京大学医科学研究所獣疫研究部
}

[受付： 3 月 31 日，1967 年]
I,はじめに
II, 病理組織学
1 , 肝病変
2 , 腸・筋の病変
3 , 脳病変

III, 病因学

1 , 形 態

2 , 培 養

3 , 病原性

4, 抗生物質感受性

IV, 発病々理

1 , 壊死巣の発現と菌増殖像

2 , 肝細胞損壊と血液 transaminase 活性の変動

3 , 感染末期の菌血症

4, Cortisone の感染増強効果

5 , 宿主栄養条件と感染

$\mathrm{V}$, 免疫

1 , 能働免疫

2 , 受働免疫

3 , 血清反応

$\mathrm{VI}$, 疫 学

1 , マウス

2 ，マウス以外の動物

VII，掠わりに

\section{I.はじめに}

肝の多発性巣状壊死を特徵とする烈しい伝染病が Harvard 大学医学部で癌移植実験中のマウスに発生し, Tyzzer (1917) ${ }^{34)}$ とつつてのの詳細が記述されたのは, 今から半世紀も前のことであつた。肝細胞および腸上皮 細胞内に発見された桿菌体の培養はえられなかつたが, 病理組織学的所見をとと Tyzzer はこれを病因と考 え, Bacillus piliformis と呼んだ。しかし感染組織材
料による感染試験では，使用マウスの污染に災されて明 確な病因学的ららづけはされず終つている。 その後, 欧米各国 $15,17,25,26,333$ はもとよりわが国22,30,32). のマウスにも同様の病気の発生が観察されて抢り, 今日 では Tyzzer 病の名のもとに実験用マウスの重要な細菌 感染病のひとつとして常に挙げられている。さらに最近, ウサギ1)の他，ラット・サルなどにも病理組織学的にマ ウスの Tyzzer 病と相同の肝病変が見出されている。

しかしながら，その非常に興味深い病理組織像にもか かわらず，この病気の感染病理学的解析は長い間なおざ りにされ，原因菌の培養がえられない故にときには感染 病として扱からことにさ疑念がもたれることもあつ た。他の多くの細菌感染病と異なり微生物学的追究がま まならないために，これも無理からぬことであつたとい えよう。1961年にわれわれは，かなり烈しい腸炎をとも なうマウスの Tyzzer 病例をみとめ30), この肝材料から はじめは cortisone のたすけをかりて，後にはこれを必 要としないでマウス継代感染を成立させることを可能に し, その典型的な肝病変を指標として実験病理学的に Tyzzer 病の発病々理・免疫などについての知見を深め たいと考えた。以下われわれの実験的研究における成績 を中心に，この病気に打ける宿主寄生体関係の一端を 述べてみたい。

\section{II. 病理組織学}

\section{1. 肝病 变}

重い病例では肝の腫大が著明で, 壞死病巣は肝の表 面・断面を問わず発現し，灰〜黄色で針尖大〜径 $2 \sim 3$ $\mathrm{mm}$ であるが, 致死例の末期には融合性となる（写真 1)。あるものでは暗赤色の中心が明瞭でいわゆる target-

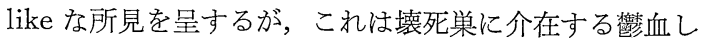
た血管を示すものである。肝壊死病巣は Tyzzer 病のみ ならず Corynebacterium, Salmonella，肝炎ウイルスの 感染でもみられるが，前 2 者では多少とも脾腫がより顕 
著であり，ウイルス肝炎では病変が早期から霉漫性にひ ろがる傾向が強いのに比して，Tyzzer 病においてはか なり末期でも個々の壊死巣がほぼ類円形であることが多 W。

組織学的にみると, 壊死栄の発現部位は様々で, Tyzzer (1917) ${ }^{34)}$ の観察した自然例では門脈域に多いとされてい るが，静脈接種によるわれわれの実験感染例ではむしろ 肝小葉内のことが多い（写真 2 )。壊死部抢よび周辺に は好中球の浸潤がみられる。もつとも特徴的な所見は Tyzzer により見出された肝細胞内桿菌体の存在であり, これは主として壊死巣周辺（写真3），ときには壊死单 からはなれた健常部 (写真4) において形態学的に生活 細胞と判断される肝細胞細胞質内にみとめられ，壊死中 心部にはきわめて少数存在するにすぎない。このように 菌体が主として壞死巣をとりまく肝細胞内に存在する像 は，感染肝凍結切片を螢光標識した抗感染マウス肝・ウ サギ抗体で処置することによつても明瞭にとらえられ， これに反して壊死中心部にはほとんど特異螢光はみとめ られない（写真 8，9）。Tyzzer はまた胆管上皮細胞内 にも同様の菌体をみとめている。しかしながら，類洞内 皮細胞あるいは星細胞内に菌体を見出すことはきわめて まれである。（写真 $5 ， 6$ ）。このように，壞死組織中 に菌体をみとめ難いことは, 後述するように in vitro で の溶菌が非常に速かにおこる事実 ${ }^{5,10)}$ と符合するととも に, この菌の厳密な生活細胞寄生性を示すものであろ う。なお, 肝細胞内菌体は haematoxylin に難染で従来 は Giemsa 染色によつて染出されていたが，われわれは Glycogen 染色を目的とした PAS 染色で偶然この菌体 沜強陽性を示すことを見出し ${ }^{13)}$ ，その後 Gomori の methenamine-硝酸銀法16) によつても菌が特異的に染 出されることを知つたので, 組織標本での菌検出がきわ めて容易となつた。

肝実質の壊死性変化に比して炎性反応が比較的弱いこ とが注目されるが，この所見はマウス継代を重ねた結果 感染力が増大し, cortisone の投与なしに致死的感染を おこした例にもあてはまるから， cortisone の影響のみ によるものではない。末期にも血管内皮細胞の肥大・増 殖，Glisson 氏鞘における細胞浸潤は著明でない。また すでに結合織の増生がおこつている感染肝では，もはや 壊死巣周辺の肝細胞内にも菌体は見出されない場合が多 W。

われわれは感染マウス肝の超薄切片電曊像によつて肝 細胞内菌体の形態および所在を鮮明にとらえることがで きた7)。その結果, 肝細胞内桿菌体が内因性の構造では
なかろうかといら疑念は全く消失するにいたつた。しか も，他の細胞寄生菌にみられるように貪喰空胞内に菌体 が集簇してみとめられることは全くなく，個々の菌体は それぞれ独立に，しかも多く平行して，宿主肝細胞由来 と思われる膜構造に囲まれた腔内に存在することが明 らかにされた（写真 10）。このことは，後述するように Tyzzer (1917) ${ }^{34)}$ が光学顕微鏡所見ですでに気ついてい たことではあるが，電顕的に確認されたわけである。さ らに一部において菌体に接する膜構造が粗面小胞体のそ れと区別できない所見を呈することは, 後述するような, 菌増殖と宿主細胞活性との密接な関係に照してきわめて 示唆に富むものといわれなければならない。Tyzzer に よつて記載されている芽胞形態についても，他の芽胞形 成菌にみられるものとそれほど違わない構造を示す電顕 像がえられている(写真 21)。

\section{2. 腸・筋の病変}

Tyzzer (1917) ${ }^{34)}$ は自然感染の 1 例で 迴盲弁附近に出 血をみとめ盲腸および結腸起始部の上皮細胞内に肝細胞 におけると同様の桿菌体を見出した。また, 盲腸の腺上皮 細胞にも多数の菌がみられることは，マウスのみならず ウサギにおいても明らかにされている1。注目すべきこ とは，すでに肝の電顕所見について述べたと同様に，腸 上皮細胞内の菌体について Tyzzer が “They are not found in masses as are many other bacteria, but are isolated from one another, each lying in a separate space within the cytoplasma of the epithelial cells." と述べていることである。われわれが感染マウス肝材 料の経口投与によつて肝病変とともにみとめたマウス・ ハムスターなどの腸上皮細胞の感染像 ${ }^{13,2}$ ¡) Allen ら (1965)1) がウサギの自然例で見出した所見も，これと全 く一致するものであつた。

Craigie (1966) ${ }^{32}$ はマウスの実験感染例で, Allen ら (1965) ${ }^{1)}$ はウサギの自然感染多数例で, 変性した心筋線 維および腸の筋層の筋細胞内に桿菌体の存在をみとめて いる。心筋線維の壊死性変化が著しい場合には, 壊死部 には芽胞型のみが見出され桿菌体は病巣周囲の見かけ上 生活細胞と考えられる筋細胞内に主として存在すること は，肝病変の場合と共通の所見である。

自然例・実験例を問わず，次に述べる脳内接種の場合 を除いては，上述した組織以外には著明な病変はみとめ られていないし，有意の菌増殖像もみとめられない27)。

\section{3. 脳病変}

桿菌体を含む感染肝材料をマウス・ラツト・ハムスタ ー・ウサギなどの脳内に接種すると, 弱毒菌でも cortisone 
の投与なしに 2 数日後脳症状をあらわして死亡する。 感染脳材料の脳内接種によるマウス継代も可能である。 経過の比較的長びいた例では肝巣状壊死もみられるが, 飢餓による甚だしい瘦削はあつても脳・肝以外の臟器に 変化はみられない。発症したマウス脳を組織学的にみる と，多くの場合脳室周辺より皮質にひろがる融解壊死像 が著明で(写真 11)，少数の好中球の浸潤がみられるが， きわめて特徵的なことは神経細胞の変性壊死とともに桿 菌体の増殖像が神経細胞細胞質内にみられることである (写真 13 16) 12,13)。ときには神経細胞内で芽胞型の形 成もみられる（写真 15）。この他，ときに脳室上衣細 胞，脈絡叢上皮細胞細胞質内にも菌堌殖像がみとめられ る。神経細胞における菌の存在様式についての電顕的 観察は目下進行中であり，近く明らかにされるである う。

感染脳組織中の菌体は形態学的所見・病原性について 感染肝組織中の菌と同じであるが，抗感染マウス肝ウサ ギ血清による間接螢光抗体法によっても抗原的同一性が 立証される (写真 17) ${ }^{12)}$ 。頻死期に脳組織の広沉な荒廃 が扔こった場合にはもはや桿菌体をみとめて難いことも 肝の場合と同様である。

\section{III. 病因学}

肝・腸病変部に見出される桿菌体を，その芽胞型をむ 含めた形態学的所見にもとづいて Tyzzer (1917) ${ }^{34)}$ は Bacillus piliformis N.SP. と記載した。この名称は 今日一般的な Bacillus 属を意味するものではなく， Bergey's Manual（第7版，1957）には収録されていな い。Dictionnaire des Bactéries Pathogènes20) には一応 Bacillus (?) piliformis Tyzzer として記載されてい るが，Wilson ら (1964) ${ }^{35)}$ はこの菌の bulb 状膨大形 態を根拠に一応 Actinobacillus piliformis として記載 し Fusiformis とも考光られると述べている。いずれに しても，この菌の名称は，培養が可能になり生物学的諸 性状がしらべられた上ではじめて定められるのであろ う。

\section{1. 形 態}

マウスあるいはウサギの感染組織中にみられる菌体の 形態については，Tyzzer (1917) ${ }^{34)}$ の刻明なスケツチを はじめとしてすべての観察がほぼ一致している。すなわ ち，大部分を占める細長い桿状体は $0.3 \sim 0.5 \mu \times 2 \sim 20$ $\mu$ で, 塗沫標本の Giemsa 染色では淡青色に染出され その長さに応じていくつかの azur に好染する核様構造 が明膫にみとめられる（写真 18 20）。Gram 陰性・非
抗酸性で thionin 染色では弱い metachromasia を呈す る。この他に, methylenblue に濃染する $1 \mu \times 5 \sim 20 \mu$ の 太い桿状体と $1 \mu \times 3 \sim 4 \mu$ の棈円形芽胞がみられるが， 前者はときとして中央に楕円形または円形の bulb 状膨 大を示すことがある（写真 19，20）。

上記核様構造はしばしば 2 ケ宛対をなしてみられる (写真 18, 19) から，この菌の最小増殖単位は 1 ケの核様 構をもつ $2 \sim 3 \mu$ の桿状体と考台られ，抢方くくは核様 構造の菌体長軸に平行方向の分裂に続く菌体の伸長，断 裂がその増殖方式であろうと想像される。このことは， すでに述べたとおり菌体が肝細胞・腸上皮細胞内で集簇 を示さないという所見とも相容れるであろう。核様構造 は電顕的には電子密度の高い中心部とこれを囲んで粒子 状小体の散在する電子密度の低、領域としてみとめられ る7)が，Feulgen 反応は陰性である。

すでに述べたように感染組織内の菌体を明瞭に染出す 方法がいくつか確立されたことは，感染発病々理の研究 の上でのささやかな大発見ともいうべきものであつた が，同時に菌体成分の一端をうかがい知る上でも意義が あろう。核様構造の部分と芽胞型を除いて菌体は PAS 陽性であるが, Allenら (1965) 'はウサギで見出した菌に ついて chloroform-methanol, diastase 処理後も PAS 染色性が変らないことなどから，中性 mucin に含まれ るような単純糖質の存在を推察している。このことか ら，この菌の 細胞親和性が，腸上皮細胞の中性・酸性 mucin 合成あるいは肝・心筋・平滑筋の glycogen 合 成と関連するのではないかと想像されている点が注目さ れる。

Tyzzer (1967) ${ }^{34)}$ の記載では桿菌体は 非運動性とされ ていて Rightら (1947)25)もこれを支持しているが, Craigie $(1966)^{2)}$ は芽胞形成のおこり 難い変異株のニワトリ 胚継代中に桿状体の運動性をみとめた。しかし形態学的 に鞭毛の存在を確かめることはできなかった。われわれ も感染マウス肝材料の位相差䫓微鏡下での観察で桿菌体 の自発性運動をみたので鞭毛染色を試みたところ陽性の 所見をえた。そこで formalin を加えた感染肝乳剤を電 子顕微鏡で観察し, 桿状菌体は多数の周毛性鞭毛を有す ることを確認し，さらに螢光抗体法によつて菌体のみな らず鞭毛が抗感染マウス肝ウ少ギ抗体を特異的に結合す ることを明らかにした9)。この事実は，さきに述べた Wilson ら (1964) ${ }^{35)}$ のいう 分類学上の位置が必ずしも 妥当でないことを示すとともに，この菌の同定上重要な 知見であるといえよう。

以上のような所見に加えて，Giemsa 染色で内部の核 
様構造がよく染出されること, 感染肝の超薄切片電顕像 そみられる菌体の電子密度の高、細胞壁構造が他の細菌 細胞にくらべてきわめて貧弱である点が注意をひくが, このことは後述するような in vitro での構造上・活性 上の不安定性と関連するものと思われる。

芽胞型はいら゙れの報告にも記載されていて $1,2,7,15,34)$ ， 塩基性色素に不染，PAS 陰性であるが，Möller 法・ Wirtz 法など通常の芽胞染色でよく染る。ほぼ芽胞と同 じ長さの桿状体の一端に接着してみとめられることがし ばしばあるが，この場合，接着点に近く塩基性色素に好 染する 1 対の小体が長軸に直角に向き合つて存在するこ とがある。超薄切片電顕像でみられる芽胞型は他の芽胞 形成菌のそれと類似の構造を示す (写真 21) ${ }^{7}$ 。興味ある ことは, Gard (1944) ${ }^{15)}$ もっているように, 芽胞形成 が宿主細胞内でみられることである。

\section{2. 培 養}

好気・嫌気条件下で種々の培地を用いて多くの研究者 が試みたにもかかわらず，Kanazawa ら (1959) 21)を除い ていづれの例でも菌の純培養はえられていない。Kanazawa らはマウス肝抽出液を加えた培地で菌が増殖した と報じているが，われわのマウス継代材料では同じ培地 で菌培養はえられなかつたし, Allenら (1965) 1) のウサギ の例でも結果は陰性に終っている。さらに，後述するよ らな免疫血清による交叉感染防御試験により，少なくと もわれわれのマウス 継代菌と Kanazawa らの培養菌と の間には抗原的共通性のないことがわかつた。Gard $(1944)^{15)}$ は連球菌との混合培養のかたちで桿菌体の増殖 をみたが，継代は不可能であつたと記載している。

Rightら (1947) ${ }^{25)}$ は血清寒天斜面においたニワトリ胚 またはマウス胎児組織で初代においては菌の旺盛な増殖 をみとめ脳内接種によつてマウスに対する病原性も確か めているが，同じ方法で継代することはできなかつた。 われわれもマウス胎児の腸・腎由来細胞の初代培養や肝 細胞由来の継代細胞などに感染マウス肝材料を接種した が菌増殖はみられず，また，秋山武久博士（慶応義塾大 学医学部）はわれわれの感染肝材料を millipore chamber に封じてマウス腹腔内に挿入したがやはり菌増殖は みられなかつたという。

これらの成績とは異なり, ニワトリ胚については, Craigie $(1966)^{2)}$ が卵黄蘘で旺盛に 菌の 増殖を観察し, われわれもマウス感染肝材料を 10 日胚の静脈内に 接種 することによつて胚肝で菌が増殖し壊死性変化をおこす ことをみとめている13)。いづれの場合にもマウスへの復 帰試験が成功している ${ }^{3,13)}$ 。

\section{3. 病原性}

感染マウス肝材料を静脈内接種するとともにcortisone を投与すると，マウスのみならずラット・ハムスター・ スナネズミ・コトンラット・レッドマウス・幼若ウサギ などの肝に肝細胞内桿菌体の増殖をともなら巣状壊死が

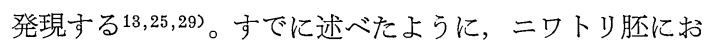
いてすら肝に特異な親和性を示すから，この菌の肝細胞 親和性はかなりひろい宿主域にわたつてみられるわけで ある。とくにハムスターでは, マウスにおいて均一な発病 をおこし難い経口接種によつてもよく典型的な肝病変が 成立することは興味深い29)。上述の各動物は感染肝材料 の脳内接種によつて致死的脳症を掞こす25,29)。しかしな がら, モルモツト・イヌ・ネコ・サル・ニワトリ・ウズラ などは大量のマウス感染肝材料静脈接種に cortisone 処 置を加えても発病せず, 脳内接種によつても脳症をおこ さなかつた。したがつてマウス継代により，マウスに対 する病原性が増大するのとはうらはらにウサギに対する 病原性が低下していることが気付かれているにしても， Tyzzer 病にもやはり一定の宿主域が 存在すると思われ る。

桿菌体が in vitro ではきわめて速かに 感染力を失な らこと, また, 接種材料には一定数の菌体が存在しない と感染が成立しないことなど12,13)を反映して, 感染材料 の維持継代は容易なことではない。死亡マウスからの継 代はほとんどの場合不可能であり, 感染肝食塩水乳剂は $4^{\circ} \mathrm{C}$ でも 24 時間後にはほとんど感染力を失なう5)。こ の場合の感染力の低下は, 可視菌数の減少と平行する。 菌数の減少は $\mathrm{Ca}^{++}, \mathrm{Mg}^{++}$などの濃度を高めると妨げ られるが,この場合にも感染力は失なわれる。また感染肝 片を $-20^{\circ} \mathrm{C}$ で保存すると菌数に変化はないが感染力は 3〜4 日しか保たれない。これに反して Craigie (1966)2 は dry ice cabinet 中に保存した卵黄震乳剤の感染力が 8カ月保たれることを観察し，また，われわれも同じ方 法で感染マウス肝組織片の感染力が 12 力月以上保たれ ることを確かめている。このような所見は, 先に述べた 桿状菌体の構造的特徵, ことにその細胞壁の状態と関係 があるものと思われる。

Craigie (1966) 23はニワトリ胚卵黄蘘で 増殖させた芽 胞形成株と非形成株を比べ, 前者では $55^{\circ} \mathrm{C} 1$ 時間加熱 後も感染力は保たれ $75^{\circ} \mathrm{C} 1$ 時間の加熱で失なわれる が, 後者では $45^{\circ} \mathrm{C} 1$ 時間の加熱で失活することを観察 した。われわれもマウス感染肝材料を trypsin 処理して 桿状菌体を除き芽胞型のみを集めてマウス脳内接種する と, 桿菌体の増殖をともなう致死的脳症を抗こすことを 
みているが，この場合の芽胞型は $65^{\circ} \mathrm{C} 30$ 分の加熱で 失活した。しかし，芽胞形成率が低いめに，芽胞型のみ の接種による典型的な肝病変の形成にはまだ成功してい ないが，疫学的に芽胞型が重要な役割をおそらくは果し ているのであるうと想像されるので今後も，検討を続け るつもりである。

\section{4. 抗生物質感受性}

卵黄襄内の菌増殖が penicillin によつておさえられる ことは Craigie（1966)22によつて報告されているが，金 子ら (1960) ${ }^{222}$ はマウスの感染に対して aureomycin が 予防効果はあるが治療効果のないことをみとめた。われ われも tetracycline がマウスにおける実験的感染をお さえることをみ, streptomycin でもある程度の効果を みたが, penicillin は無効であつた ${ }^{28)}$ これは Craigie (1966) 2) の成績と矛盾するが，それぞれ宿主を異にする in vivo の成績であり，この菌の細胞寄生性を十分考慮 に入れた上で，感受性パターンや作用機序についてなお 十分検討しなければならないと思われる。

\section{IV. 発病病理}

継代感染肝材料のマウス接種による特徵的な病変の成 立に関連して今日までにわれわれのえた知見はきわめて 断片的ではあるが，拉よそ次のようなことがらである。

\section{1. 壊死巣の発現と菌增殖像}

Tyzzer 病におけるもつとも特幑的な肝壊死栄の中心 部に桿菌体が少ないことから，病巣発現の初期に接種菌 がどのような姿でとらえられるかをしらべてみた ${ }^{13)}$ 。感 染肝乳剤の静脈内接種後数日で死亡する場合について経 時的に肝病巣の推移を追つてみると, 接種後 20 24 時間を頂点とする類洞内皮・星細胞の肥大・増数がみら れるがこの段階では菌体はどこにも見出されなかつた。 肝細胞の壊死はこれより教時間後の例にはじめてみとめ られる。発現部位は小葉内であることが多いが，しばし ば門脈周から病巣がひろがる場合もある。当初からすで 飞少数の好中球の参画がみとめられる。注目すべきこと 飞，このような 1 〜数ケの肝細胞に関する初期病巣です でに PAS 陽性桿菌体が病巣中にみとめられ，これに接 した肝細胞に単一菌体がみとめられた例もある。さらに 壞死性変化の 進展した 場合でも，壞死巣からかなり 離 れた位置の肝細胞内に多数の棉菌体が みとめられなが ら，周囲に何らの炎性反応をみない場合がある（写真 4)。このような所見は, 感染が個々の肝細胞単位でお こることをはつきり示し，培養細胞でのウイルス感染に analogy を求められるようにさえ思える。をた, 感染耐過
動物では肝壊死巣の修復過程において有系分裂像を示す 肝細胞内に明瞭な菌体を見出した例むある ${ }^{8)}$ 。

以上の所見から，実験 Tyzzer 病における肝壊死巣の 発現には稈菌体がその当初から関与し, 肝細胞と密接な 交渉をもつことが明らかにされたが，進展した壊死中 心に菌体が少ないことの理由としては, 既述のように 生活細胞から離れた菌はきわめて構造的に不安定で速か に溶菌を抏こす事実 ${ }^{5,10)}$ が挙げられる。保存により可視 菌体が消失し感染力を失なつた感染肝材料に高い抗原活 性が証明されることもこのことをららづけている。この ような理由から, Tyzzer 病に扔いては病変の強さと存在 する菌数とは必ずしも一致しないことがしばしばあり， これまで感染肝材料による感染実験の成績が不安定であ つたこと 22,26$)$ 首肯されよう。また，菌体外毒素が病変 の成立に関与してはいないかという可能性は, 上記保存 感染肝材料がマウスに強い感染防禦能を与えるにもかか わらず何らの毒性・病原性を示さないこと10)から否定で きる。

感染肝・脳材料のマウス脳内接種によつてできる病 巣は，おそらく脳室壁から進展するものと考えられる が, 結果的には脳組織の広沉な荒廃をまねき末期にはか えつて可視菌体数の著減をみることは肝の場合と同様で ある12)。たとえばアンモン角における病変の進展を追つ てみると, 錐体状細胞層の急速且連続的な崩壊に比して 顆粒層の損壊ははるかに扩くれて発現する(写真 12)。こ のような事実は, 細菌感染としては他に類をみないこと であろう。静脈接種で致死的肝変化を成立させるために は $10^{4}$ 以上の菌が必要であるが，脳内接種の場合は $10^{2}$ 以下の菌でも発病することは，すでに述べた肝病変成立 に㧍ける間葉系細胞の態度とあわせ考えて， target 以 外の宿主細胞に対するこの菌の無力さを物語るものと いえよう。

\section{2. 肝細胞損壊と血液 transaminase 活性の变動}

肝細胞の損傷をともなう疾患, たとえば四塩化炭素中 毒やウイルス性肝炎などと同じく, 実験 Tyzzer 病にお いても黄疸が発現し血中 transaminase 活性が著しく上 昇する ${ }^{14)}$ 。正常 ICR マウスの血漿中 glutamic-pyrubic transaminase (GPT) 活性は 50 Karmen 単位 $/ \mathrm{ml}$ 以下 であるが， cortisone 処置を加えた感染で肝巣状壊死が 肉眼的にみとめられる段階では $100 \sim 1,000$ 単位 $/ \mathrm{ml}$ と なり死亡時には 5,000 単位 $/ \mathrm{ml}$ を超えることさえある。 さらに, 感染肝に㧍ける可視菌数の増加と壊死性変化の 発現進展に平行してこのような血漿 GPT 活性の上昇が おこることが明らかにされた。この間, 血漿中 glutamic- 
oxalacetic transaminase (GOT) 活性も GPT と同じ 割合で上昇するが,感染のどの時期をとつてみてもGOT/ GPT 比は $1.89 \pm 0.26$ (95\%信頼限界) である ${ }^{24) 。 こ ~}$ の価を正常マウス主要組織についてしらべた GOT/GPT 比(肝 $1.74 \pm 0.47$ ，心 $29.9 \pm 9.1$ ，腎 26.1 :上8.3, 肺 6.34 \pm 1.63 , 脾 $13.1 \pm 5.3$, 脳 $41.2 \pm 15.2$, 血漿 $2.64 \pm 0.60$ ) とくらべると,肝のそれにもつとも近い。したがつて, 感 染にともなつて上昇した血中 transaminase 活性は肝細 胞の変性壊死による酵素の流出を示すものとみてもよい であろう。このように，肝細胞の変性壞死の程度を客観 的にかなり正確にとらえることができたことは以後の研 究に資すること大であつた。なお，このように顕著な transaminase 活性の変動とは対照的に血中 phosphatase 活性の変動がほとんどみられなかつたことにより， Tyzzer 病における網内系細胞の消極的な 役割が改ため て認識される。

\section{3. 感染末期の菌血症}

肝の壤死性変化の進行につれて上記のように血中 transaminase 活性が 上昇しはじめる時期より僅かにおく れて，末梢血中に菌が出現し感染の進行とともにその数 が詨数的に増加し, 死亡時には $10^{6} \sim 10^{7} / \mathrm{ml}$ に達する。 このような 菌血症の 発現頻度・程度は菌の病原性およ び cortisone の負荷によつて異なるが，血中菌が検出可 能(約 $10^{3} / \mathrm{ml}$ ) となるのは常に肝菌数が $10^{7} / \mathrm{g}$ となつた 段階においてである27)。致死的感染では血中菌数の対数 值は直線的増加を示し, その速度は肝にくらべて約 3 倍 である。この事実は実験チフス症における 2 次敗血症の 場合に肝・血液菌数の増加速度がほぼ等しいと報告され ている19)ことと対比して興味深い。Tyzzer 病の場合, 菌増殖の場が構造的に脆い肝細胞であり多数の感染肝細 胞の崩壞が菌の massive な血中への放出をむたらすのに 対して, 実験チフス症においては菌増殖の場である網内 系細胞の抵抗性がかなり強く, 細胞が崩壞することなし に血中への菌放出を続けるのではないかとも考えられ る。

病理組織学的に菌血症をおこしたマウスの主要藏器を しらべてみると，肝に扝いては肝細胞崩壞にともなら菌 の類洞への放出がみとめられる（写真 7 ）が，血管内皮 あるいは星細胞が積極的な役割を演じている像はみとめ られない。また，腎・肺・脾・腸間膜リンパ節などでは 脈管内に少数の菌集簇はみられるが, 有意の菌増殖像や 炎性反応は全くみとめられない277。

\section{Cortisone の感染増強効果}

Tyzzer 病の自然例の多くは潜在感染の域を出ないも
のであり 14,30,32)，その肝材料からマウス継代感染を成立 させるためには cortisone または hydrocortisone が用 いられた $14,22,30,31)$ 。現在われわれはマウス継代を重标て cortisone の投与なしに致死感染を㧍こす強毒菌を維持 し, 複雑なホルモン作用をぬきにして Tyzzer 病の研究 を行なうてだてをもつているが，次に述べるようにこの 病気、におる cortisone の効果は他の細菌感染における とはやや趣を異にするように思われる。

周知のように, cortisone は多くの細菌感染において 感染疃強効果を㐫らわすが，一般には 比較的少量の木 ルモンを頻回，感染前に 投与して網内系の活性を低下 させることにその意義が求められる。ところが，実験 Tyzzer 病に执いては接種前に与えた cortisone は全く または部分的にしか効果なく，接種直後または間もなく 投与した場合にもつとも効果が大きい14)。接種後種々の 量の hydrocortisone acetate を毎日投与した場合につ いて先述した血中 GPT 活性の変動をみると, 投与ホル モン量に比例して感染が増悪されることがわかる。この ような効果は, hydrocortisone acetate, predonisolone acetate では cortisone acetateよりむしろ強いが, desoxycorticosterone acetate や testosterone propionate は全く無効である。

かりに, cortisone などの glucocorticoid 作用が直接 肝細胞内菌増殖を促進するものだとすると, Allenら ${ }^{1) も ~}$ いうょうに, 菌の PAS 陽性や感染肝細胞に扝ける glycogen 消失の所見などから, 菌増殖と肝細胞の糖代謝活 性との関連が示唆される。たとえば接種と同時に日量 $0.5 \mathrm{mg}$ の cortisone を投与したマウスで肝 glycogen の 動きをみると, 接種 24 時閒では約 4 〜 倍に増加するが 以後減少して肝病変のもつとも著明となる時期には正常 值以下になる。このような glycogen の動きは cortisone 投与·非感染のマウス肝でも同じである。菌増殖による病 変の発現と肝 glycogen 量の推移から, 蓄積した glycogen が菌の増殖を促進するかも知れないという可能性が 考えられるが，これは次に述べる実験的事実によつて否 定的である。

\section{5. 宿主の栄養条件と感染}

飼料の形状，栄養が Tyzzer 病の自然発病に影響する ことは以前から考えられていた ${ }^{15,25)}$ が，前項に述べた肝 glycogen 量に関連した観察の過程でたまたま感染マウ スを飢餓状態に掞いたところ，所期の肝病変が発現しな いことに気づいた。この点について吟味してみると次の ように興味ある事実がわかった23)。

致死菌量を感染させたマウスに水だけを与えて 3 日間 
絶食させると肝病変の発現が抑制され，生残日数もかえ つて延長するが，接種前 3 日間の絶食ではこのような効 果がみられない。さらに，感染マウスにそれぞれ $30 \%$ W/V の glucose, lactose, sucrose または $15 \%$ W/V の peanut oil, casein を添加した 寒天ブロツクを与え, 4 日後の肝病変形成をみると, casein 給与群のみに市販 固型飼料（粗タンパク含量 $26.5 \%$ ）給与群 とほぼ同程 度の肝変化がみられたが，他の群では明らかに肝病変の 形成がおさえられていた。前項で述べた知見と関連して 各群の肝 glycogen 量をみると, ほぼ同程度の肝変化を 示した固型飼料群 (6.0 30.0 mg/g 肝) と casein 群 $(0$ $\sim 1.6 \mathrm{mg} / \mathrm{g}$ 肝）との間には大きな開きがあり，全く病 変をみとめなかつた糖給与群に当然のことながら多量の glycogen 蓄積 $(30.0 \sim 40.0<\mathrm{mg} / \mathrm{g}$ 肝) がみられた。 つぎに，合成飼料を用いた実験で，飼料中の casein 量 を低くすると感染マウスの生残日数が延長し，無タンパ ク飼料では肝病変が成立しないことも確かめられた。さ らに, casein 以外のタンパクまたはアミノ酸を単味で加 えても casein と同量で所期の病変が形成されることも わかつた。これらの事実に反して, Salmonella abortusequi のマウス感染ではタンパク含量が 感染経過に大き く影響するという所見はえられなかつた。

以上のことから, Tyzzer 病における肝細胞内菌増殖 および壊死病変の発現は, 肝細胞の糖質代謝よりはむし ろアミノ酸・タンパクの代謝と密接な関連をもつことが 示唆される。この点で電顕所見における菌の所在と肝細 胞内膜構造との関係は非常に示晙に富んでいる。しか も, 多くの細菌感染が, 低タンパク・低アミノ酸給与によ り増悪されること文と全く対照的な知見がえられたこと は, Tyzzer 病に捛ける菌の厳密な細胞寄生性とも関連 して興味深い。菌体のPAS 陽性物質の本態についてはい まだ明らかではないが，後述するように感染肝由来の特 異抗原活性が抢そらくタンパクに関するものであろうと いら知見と合わせて，今後菌体成分や感染機序の研究が 進められるにつれて次第に明らかにされるであらう。

\section{V. 免疫}

これまでに述べてきた実験的諸事実は，いづれも従来 考えられてきたように.Tyzzer 病が外因性の感染病であ るとすることと矛盾しない。だとすると，当然感染にと もなつて免疫学的諸現象が観察される筈である。この面 でわれわれがこれまで検討したことを以下に述べる。

\section{1. 能働免 疫}

金子ら (1960) 22) は formalin 処理感染肝をワクチン
としてマウスコロニーに適用した場合に十分な効果は挙 げられなかつたが，実験感染では多少の死期延長がみと められたと述べている。われわれも重い肝変化を示す感 染マウス肝乳剂を formalin 処理した材料 (formalin vaccine; 約 $1 \times 10^{7} / \mathrm{ml}$ の菌体を含む) でマウスを前処 置すると, cortisone を負荷した致死的攻撃に対する強 い感染防御能が与えられることをみた ${ }^{81}$ 。この場合，肝 病変の形成そのものがおさえられる。このような感染防 御効果は, 上記 formalin vaccine を攻撃 $1 \sim 2$ 週前に $0.1 \mathrm{ml} 1$ 回だけ皮下接種した場合にも 1 部の 動物は攻 撃に耐えるが，数日の間隔をおいて 3 回以上前処置する ことにより完全な防御効果が期待できる。また, 前処置 は静脈・皮下・腹腔いづれの経路でもよいが, 経口投与 は無効であつた。頻回の前処置によつてえられた感染防 御能は長期間持続し， 8 カ月後にも cortisone 負荷をと もなう攻撃に耐過した。また，現在われわれの維持して いるマウス継代の弱毒・強毒菌8) とついて交叉感染防御 試験を行なつたところ，相互に感染防御が成立すること が明らかにされた。これに反して, 形態学的にいささか の類似を示す Clostridium 属菌 $(\mathrm{Cl}$. butyricum, $\mathrm{Cl}$. histolyticum, Cl. oedematiens および $C l$. septicum) 培 養から 調製した formalin vaccine（宮崎大学農学部・ 新城敏晴博士から分与を受けた）は Tyzzer 病の感染防 御に全く無効であつたし，マウス糞便から分離された数 株の有芽胞嫌気性菌について同様の実験を行なつてみた がやはり陰性であつた。

以上のように, formalin 処理感染肝材料の 前処置で 強、感染防御能が附与されるのに反して, 生の感染肝材 料はたとえ含有菌数を確認して接種しても, マウスに感 染防御能を与える能力が低い8)。たとえば $10^{6} \sim 10^{7}$ の菌 を含む 新鮮感染肝材料を 皮下または腹腔接種し 同時に cortisone を負荷した場合に，一部のマウスは感染死する にもかかわらず生残マウスは 3 週後の静脈内再感染に際 して均一な抵抗性を示さず，一部の動物はかなり重い肝 変化を示し死亡することもある。また第 1 回接種が経口 投与の場合には，とくに効果がうすい。また，103〜104 以下の菌をもつてする $1 \sim 2$ 回の接種では, たとえそれ。 を静脈内に行ない cortisone を負荷しても, $3 \sim 12$ 週後 の静脈内再接種に際して一部の動物に感染防御がみられ。 るのみである。

このような事実からすると, 新鮮感染肝材料の前処置 によつてもたらされる感染防御能は導入された菌そのも のの抗原物質量にみあうものでしかないとさえ感ぜられ る。肝細胞以外では菌増殖が抗こりえないらしいとの病 
理組織学的所見をあらためて思いおこすとともに，先に も引用したような他の細菌感染における生菌免疫の強固 であることに比して興味深い知見である。Tyzzer 病では 致死的肝病変の成立には強毒菌といえど。 $10^{3} \sim 10^{4}$ の 菌の静脈内接種を必要とし, 網内系細胞などの barrier を超えた一部の菌が肝細胞に到達増殖してはじめて量的 に十分な免疫原としの意味をもつのかも知れない。ある いはまた，他の細菌感染と等しく，喰細胞系には 1 次 接種により多少の感染免疫が成立していても, prime target である肝細胞にはそれが成立し難いために再感染 菌の増殖を許してしまうのであろうか。これらの点に関 しては今後の解析にまたねばならないが，いずれにして も Tyzzer 病の免疫を考える上で重要な知見というべき であろう。

感染肝材料に formalin を加えない場合には，きおめ て速かな溶菌現象がおこることはすでに述べた。この場 合, 遠心上清に強い感染防御抗原が証明され, その活性 分画は硫安 $2 / 3$ 飽和で塩析され, ether, 3 塩化酶酸で抽出 されないが, trypsin 処理によつて失活する10)。後述す るように, 同じ上清の補体結合掠よび沈降抗原も硫安 $2 / 3$ 飽和で沈澱することがわかつている。これらの感染肝 材料にみられる抗原活性を追究することは, 培養菌が使 えない現段階では菌体成分の一端をうかがい知るための 重要なアプローチとなるであろう。

\section{2. 受働免疫}

前項に述べたような formalin vaccine の前処置効果 にもとずいて, 感染防御における血中抗体の役割が検討 された。最初に formalin vaccine 前処置後感染耐過マ ウス血清打よび感染マウス肝材料で頻回免疫したウサギ 血清と感染肝材料とを, あらかじめ $4^{\circ} \mathrm{C}$ また $37^{\circ} \mathrm{C}$ で incubate してからマウス静脈内に接種して抗血清の 作用をみた。正常マウス血清および正常マウス肝免疫ウ サギ血清にくらべて, 前記抗 Tyzzer マウスまたはウサ ギ血清はより速かに感染肝材料の感染力を失活させるこ とは確かであるが, 先述したように, 対照においても in vitro での感染力低下が速かに抗こるために免疫血清 の特異作用を十分見きわめることが困難であつた。そこ で抗血清を感染肝材料接種の前後にマウスに直接投与し てその感染防御勃果をしらべたところ, 次のような知見 がえられた ${ }^{11)}$ 。

感染肝乳剂のマウス静脈内致死攻撃の 7 日 2 時間前 に抗感染マウス肝ウサギ血清または耐過マウス血清 (1:

$4,0.1 \mathrm{ml})$ を静脈注射することにより, 攻撃後の肝病 変の進展がおさえられ感染死は完全に防御される。攻
撃前 $2 \sim 3$ 週前に抗血清を注射してもかなりの効果があ る。攻撃 10 分前の抗血清注射で約 $2 / 3$ が生残したが, 攻 撃 10 分後の処置では約 $1 / 3$ のみが攻撃に耐え, 攻撃 2 時 間以後の処置は全く無効で，正常マウス肝免疫ウサギ血 清・正常マウス血清前処置の対照群と同様, 重、肝病変 を示し数日で死亡した。攻撃後の抗 Tyzzer 血清処置は たとえ反復行なつても無効であつた。階段稀釈した抗 Tyzzer 血清を $0.1 \mathrm{ml}$ 静脈注射して数時閒後に感染肝 乳剤で攻撃し, 死亡率㧤よび肝病変の程度を比較するこ とによりこの実験に用いた抗 Tyzzer 血清の感染防御力 価をしらべてみると $1: 32(0.1 \mathrm{ml})$ まで過半数のマウ スを感染死から防御することができた。

攻撃前に与えた場合に, $56^{\circ} \mathrm{C} 30$ 分加熱した抗血清は 有効であるが $80^{\circ} \mathrm{C} 30$ 分加熱により防御能は失活する。 また, 静脈内のみならず皮下・腹腔に与えても有効であ る。さらに, 少なくとも抗感染マウス肝ウサギ血清に関 しては Sephadex G200, DEAE cellulose などによる 分画で, 主として IgG 分画に感染防御活性があること がわかっている。

抗 Tyzzer マウスまたはウサギ血清を正常マウス肝ま たは感染マウス肝から調製したアセトン末と $4^{\circ} \mathrm{C} 48$ 時 間 incubate してからその上清をマウスに注射, 翌日攻 撃して感染防御力価をしらべてみると, 抗血清の感染防 御力価は感染肝末との incubation により著明に 低下す るが，正常肝末との inculation では、変化しないことが わかつた。また，抗感染マウス肝ウサギ抗体が, Tyzzer

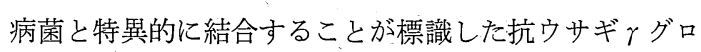
ブリン・ヤギ血清による間接螢光抗体法で観察された。 抗血清を感染肝末で吸収した後にはこの特異螢光は陰性 であった。

以上の所見から，感染耐過マウス抒よび感染マウス肝 免疫ウサギ血清中には菌に直接㗢いてその感染力を失活 させる抗体が存在すると考えられる。また，この抗体は 菌が肝細胞内に占座した後にはもはや作用しないことが 示唆される。その細か、作用機作についてはウイルス中 和抗体などに関する知見を参照して今後検討されなけれ ばならないが，このような感染防御抗体の存在は次項に 述べる in vitro の血清反応とともに Tyzzer 病の免疫 を解析する上で，重要な知見のひとつである。

\section{3. 血清反応}

すでに述べたように, Tyzzer 病感染肝乳戍の感染力 は in vitro できわめて不安定であり, 菌体数の減少とと もに速かに低下，消失するが，これにともなつて上清に 感染防御抗原が証明される10)。この病気の免疫学・疫学 的研究の一環として, このような保存感染肝乳凨上清の 
抗原性を, 前処置後の攻撃に耐過したマウスの抗血清に 対する補体結合 $(\mathrm{CF})$ 反応抢よび寒天ゲル内沈降反応で 検討してみた 5 。

感染肝抗原と抗血清は寒天ゲル内で明膫な 2 本の沈降 帯を形成するが，このような沈降帯は正常肝抗原と抗血 清の間, 感染肝抗原と正常血清との間には形成されない。 また, ether 処理感染肝抗原は抗血清と反応して高い $\mathrm{CF}$ 価を示しゲル内で 2 本の沈降帯を形成するが， $56^{\circ} \mathrm{C} 30$ 分加熱抗原では沈降帯が明瞭にあらわれず $\mathrm{CF}$ 值も低 い。また, 感染肝材料中の $\mathrm{CF}$ 抗原は硫安で塩析される が， $2 / 3$ 飽和沈搌分画と $1 / 3$ 飽和沈澱分画の比活性をタン パク $\mathrm{mg}$ あたりについてみると前者が約 8 倍は高い。ま た, 沈降抗原は硫安 $1 / 3$ 飽和で沈澱せず $2 / 3$ 飽和で沈澱す る。由来およびマウス継代数の異なる菌による感染肝か ら調製した抗原は互に交叉して反応し，既述の能働的・ 受働的感染防御試験の結果と一致した。当然のことなが ら, 同じょうに壊死性変化を示すマウス肝炎ウイルス 感染肝抗原および抗血清は, Tyzzer 病肝抗原㧍よび抗 血清と $\mathrm{CF}$ ・沈降いづれの反応によつても交叉反応を示 さない。

以上のような血清反応が確立されたことにより, 感染 防御試験とともにこの病気に関する免疫学的解析がある 程度可能になつた。さらに実際面でも, 後述するように 退役種親マウス血清による CF 反応と幼若マウスの cortisone 誘発試験を併用してマウス集団の污染をしら べることが試みられており 5,322, 動物生産管理の上に寄 与するところがあると思われる。しかしながら， CF 抗 体による污染検出の感度は必ずしも満足すべきものでな く，今後さらにより鋭敏な反応の開発が望まれるが，い ままでのところでは上記感染肝濃縮抗原を用いた閒接血 球凝集反応は成功していない。

\section{VI. 疫 学}

\section{1. マウス}

Tyzzer (1917) ${ }^{34)}$ は “Japanese waltzing mice”が “common mice”にくらべて高い感受性を示したと述 べている。その後 Gowen ら (1933) ${ }^{18)}$ は, Ten Broeck が中国の北京から Rockefeller Institute に持帰つた Tyzzer 病感染マウス材料について感受性に関する遺伝 的検討を行ない, “Mus bacterianus” および “Mus muscularis” の交配実験によつて，感受性が waltzing factor とは別の単一優勢遺伝子の支配を受けており, 優 勢白色因子・性とは link しないことを明らかにしてい る。感受性が性によつて違わないことは金子ら (1960) 22)
によつても観察されている。われわれも実験感染におい て ICR マウスが DDD, CFW, C3H などにくらべて 著しく感受性が高いことは知つているが，感受性の遺伝 支配に関する系統的な実験はまだ行なつていない。

Gard $(1944)^{15}$ は 4 5 週令までの幼若マウスでは腸 炎が主徵であり, Tyzzer 病特有の肝壊死巣はむしろ成 熟マウスで一般的な病変であるとしている。たしかに幼 若マウスは成熟マウスにくらべて実験感染に対する感受 性が大であるが，静脈接種では腸炎はほとんどみられな 、事実にかんがみて, 幼若マウスでは病勢が急性に経過 するために肝変化を抢こすにいたらないのであらう。金 子ら $(1960)^{22)}$ は仔の剖検によつて相当する親の感染を高 率に発見しうると述べ，われわれも cortisone 誘発試験 が幼若マウスについては効果的であるが，成熟マウスで はそれほど効果的でないことを見ている14,32)。

Tyzzer が記載したような急性例は 自然にはむしろま れで, 污染は通常潜在感染のかたちをとることが多い322。 しかし，種々の実験では自然にはおこりえない強烈な stress が課せられるから，繁殖飼育コロニーではほとん ぞ障害をおこさない潜在感染が実験操作によつて顕性化 し実験成績のよみとりを不可能にすることは十分考えら れる。Tyzzer (1917) ${ }^{34)}$ の最初の 報告そのものが癌移椬 実験中のマウスに関するものであり Gorer (1944)17) む 発癌物質の注射が Tyzzer 病誘発に関係があるらしいと 考えている。この他, 季節の変動 ${ }^{33)}$, 暑気と湿潤な飼 料15)，過密飼育25)なども流行の誘因と考えられている。 いづれにしても，実験用マウスの母集団における潜在感 染を含めた污染の有無を絶えずしらべておくことは実験 の正確を期する上で必要となってくる。

前述したように Tyzzer 病の感染を増幅する cortisone はまた，不顕性感染の摘発に用いることができる ${ }^{14,32) 。 ~}$ 通常 $3 \sim 5$ 週令の幼若マウスの皮下または筋肉内に cortisone acetate $2.5 \sim 5 \mathrm{mg}$ を投与して 7 10日後殺 し て剖検し肝変化および病巣の菌の存在をしらべるのであ るが，污染の程度によつてはこの期間内に重い肝巣状壊 死を示して死亡する例もある。たとえば, 1965年 8 月から 1966年 1 月まででの間に 5 繁殖コロニーについてしらべ た成績32)では，cortisone を注射した $4 \sim 5$ 週令マウス 438 匹中 55 匹 $(12.5 \%)$ 亿yzzer 病感染を検出した が同期間中に同じコロニー由来の同令マウスを無処置で 剖検した場合には 14,950 匹中 32 例 $(0.2 \%)$ のみが Tyzzer 病と診断された。これら5コロニーの污染度に はかなりの開きがあり， cortisone 誘発による検出率は 最低で 175 匹中 18 匹(1.0\%)，最高で 83 匹中 14 匹(16.9 
\%)であつた。成熟マウスでは, おそらくは感受性の低下 と免疫状態の成立のために cortisone の誘発効果は幼若 マウスにおけるほど顕著ではない14,32)。幼若マウスの cortisone 処置は Tyzzer 病のみならず, 肝炎ウイルス, HVJ, Corynebacterium kutscheri などの潜在感染摘発 にも有効である ${ }^{5,14,32) 。}$

繁殖コロニーで陶汰される退役種親マウスは上述のよ らに cortisone 誘発試験には不向であるが，その血清を個 体別にしらべて CF 抗体を検出することにより Tyzzer 病污染をある程度知ることが可能である5)。たとえば，上 に挙げたように幼若マウスの cortisone 誘発試験によつ て Tyzzer 病の污染をみとめた 5 コロニーの中 4 コロニ 一の退役種親マウスについて 1966 年 2 月〜 9 月に行な つた CF 抗体の検出率は 1,511例中 123 例 (8.1\%) で あつたが, cortisone 誘発試験で陰性であつた他の 3 ב ロニー由来の退役種親マウス血清は 646 例全部が陰性で あつた。しかし，その後も多数例についての検索を続け た結果, Tyzzer 病污染を有効に 摘発するためには，幼 若マウスに打ける cortisone 誘発試験と退役種親マウス 血清反応を併用すべきであるとの結論に達している。こ の点で血清反応のみできわめて鋭敏に污染を知ることが できるように思われる C. kutscheri や HVJ の感染亡 はやや趣を異にする6)。

われわれの経験した病例も多く不顕性感染の域を出な いものであり， cortisone 誘発その他の stress を負荷す ることによつてはじめて污染を知る場合が多いことはす でに述べた。しかしながら，発病の前提となるマウス集 団の污染がどのような疫学的パターンを構成している かについては今日なおほとんど不明である。Tyzzer (1917) ${ }^{34)}$, Gard (1944) ${ }^{15)}$, Right ら (1947) ${ }^{25)}$ のいうよ うに飼料の污染による経口感染, Saunders (1958) ${ }^{26)}$ が述 べているようにマウス腸管菌叢としての存在，などに関 する実験的な証拠は不十分だとしても，菌の增殖型が in vitro できわめて不安定なことに照して endemic な 型の污染には芽胞型が重要な役割を果していることが十 分考えられる。この面から, Tyzzer 病菌の芽胞形成・ 発芽に関する知見が今後の重要な課題であるし，污染を 有効に察知するためのより 鋭敏な血清反応の開発が望ま れる。また，cortisone 注射によつて潜在感染を増幅さ せた上で一定時日後血清抗体を検出する方法についても 目下検討中である。

\section{2. マウス以外の動物}

久しい間, Tyzzer 病はマウス固有の病気と考兵られて いたが，数年前石田葵一博士 (東京大学農学部) が多発性
巣状壊死とともに肝細胞内桿菌体が明膫に見出されるラ ット肝の標本を示された。その病変はマウスの場合のも つとも烈しい変化に匹敵する程度のもので, 病理組織学: 的には壞死巣周辺の細胞浸潤がかなり強い他はマウス実: 験例とほとんぞ同じである。その後, 高垣善男学士 (中外 製薬綜合研究所）もタンパク同化ホルモン投与ラットで 同様の肝病変を観察した。これらのラットの例からのラ ツト，マウスーの継代感染は試みられていないので，わ れわれも目下ラットの自然例を見出すべく努めている。

1960 63 年に米国 National Institute of Health . ウサギに，マウスの Tyzzer 病と症状・病理学的所見の 相同な流行性疾患が発生し, Allen ら (1965) 1) はその 肝・腸・心筋などの病理組織学的変化についてくわしく 観察するとともに cortisone 処置ウサギに累代感染を拉 こさせることに成功している。さらに，われわれは英国 National Institute for Medical Research の Dr. J. S. F. Niven から, 薬剤投与試験に供されたサルの肝に巣状壊 死とともに多数の肝細胞内桿菌体がみとめられる標本の 恵与を受けている。

以上の各動物種において共通の病理組織学的所見が, 同一種の微生物を病因とするものであるかどうかは重要 な問題であるが，現在まだ検討されていない。すでに述 べたごとくわれわれの感染マウス肝材料はウサギを含 む種々の動物にマウスと同様の肝変化をおこす ${ }^{13,29)}$ し， Allen ら (1965)11)のウ少ギ感染肝材料もその後マウスー の病原性が確認されたと聞いている。原因菌の分離培養 による比較は不可能であるにしても，先に述べたような 手続きで免疫学的にそれぞれの異同を検討することは可 能であるから，近い将来にこの点が明らかにされるで あろう。

\section{VII. おわりに}

以上述べた諸事実によつて，Tyzzer 病におけ㐨細胞 内桿菌体の病因としての役割や宿主細胞活性と密接な関 連のもとにあらわれるその病原性について考える上に， かなりの素材が提供されたと思われる。このように微生 物としてはきわめて大型の部類に属する寄生体が，肝細 胞・腸上皮細胞・神経細胞・筋細胞などのように宿主の 生命維持に重要な一環を担うべく特殊に分化した細胞を prime target とし，抒そらくはその何らかの代謝活性 に厳しく依存して 増殖し 細胞病原性をあらわすとすれ ば，細菌の感染現象としてはきわめて特異なものとい兄 よう。これまで知られている，細菌による宿主細胞を場 とする感染，たとえば Salmonella 属・Brucella 属菌な 
どの感染では，標的細胞が主として構造的・機能的に異 物処理あるいは炎性反応への参画を使命とする閒葉系の 細胞であることを考えると，寄生体の大きさを別として Tyzzer 病の感染はある面ではむしろウイルス感染にそ の analogy を求められるようにさえ思われる。

しかしながら, Tyzzer 病の研究は, ようやくその素 描ができつつある段階であり，われわれによつて明らか にされた実験的諸事実にしても感染症としてはいわば当 然な諸現象の確認の域を出ないものであり，この病気の 本質的な解析は多く今後に残されている。マウスにおい て防除すべき疾病のひとつという限られた話題にすぎな かつたこの病気に関する知見が次第に増すにつれて，わ れわれのささやかな研究に対しても内外の関心が少なか らず寄せられていることに励まされて，これからもこの 興味深い宿主寄生体関係の解明に努力を続けたいと考え ている。

稿を終るにあたり，実験動物およびその感染症研究の 道を拓かれ終始ご激励ご助言をいただいた田嶋嘉雄教授 (東京大学医科学研究所), 感染病理学の素養を培つてい ただいた山本脩太郎教授(東京大学農学部)に心からの尊 敬と感謝の意を捧げるとともに，かけがえのない多数の 動物を供与された野村達次博士(実験動物中央研究所) 掠 よびこの稿を公にすることをすすめられた尾形学教授 (東京大学農学部)に厚くお礼申上げる。

また，当初から現在な打ひきつづいて協同研究者であ る高垣善男学士 (中外製薬株式会社綜合研究所)，それぞ れ研究の一部を担当した故福田章一博士，高橋令治博士 (国立予防衛生研究所), 内貴正治学士 (信州大学医学部) および前島一淑・倉科宏彰・松沼尚史の各学士（東京大 学医科学研究所）の努力に敬意を表するとともに，技術 的協力を惜しまなかつた谷島百合子技官に感謝の意を表 する。

\section{文献}

1) Allen, A. M., Ganaway, J. R., Moore, T. D. and Kinard, R. F. (1965): Tyzzer's disease syndrom in laboratory rabbits. Amer. J. Path., 46, 859-882.

2) Craigie, J. (1966) : 'Bacillus piliformis'(Tyzzer) and Tyzzer's disease of the laboratory mouse. I. Propagation of the organism in embryonated eggs. Proc. Roy. Soc. B, 165, 35-60.

3) Craigie, J: (1966) : 'Bacillus piliformis' (Tyzzer) and Tyzzer's disease of the laboratory mouse. II. Mouse pathogenicity of B. pili- formis grown in embryonated eggs. Proc. Roy. Soc. B, 165, 61-77.

4) Dubos, R. J. and Schaedler, R. W. (1958): Effect of dietary proteins and amino acids on the susceptibility of mice to bacterial infections. J. Exp. Med., 108, 69-81.

5) Fujiwara, K. (1967) : Complement fixation reaction and agar gel double diffusion test in Tyzzer's disease of mice. Japan. J. Microbiol., 11, 103-117.

6) 藤原公策 (1967)：血清反応によるマウス繁殖集 団に打ける感染検出の試み. 実験動物, 16, 4751.

7) Fujiwara, K., Fukuda, S., Takagki, Y. and Tajima, Y.(1963) : Tyzzer's disease in mice: Electron microscopy of the liver lesions. Japan. J. Exp. Med., 33, 203-212.

8) Fujiwara, K., Kurashina, H., Maejima, K., Tajima, Y., Takagaki, Y. and Naiki, M. (1965): Actively induced immune resistance to experimental Tyzzer's disease of mice. Japan. J. Exp. Med., 35, 259-275.

9) Fujiwara, K., Kurashina, H., Matsunuma, N. and Takahashi, R. (1968): Demonstration of peritrichal flagella of Tyzzer's disease organism. Japan. J. Microbiol., 12(3), in press.

10) Fujiwara, K., Kurashina, H. and Takagaki, Y. (1965) : Propriété immunogène du surnageant de l'homogénat du foie de la souris atteinte de la maladie de Tyzzer. Compt. Rend. Soc. Biol., 159, 2101-2106.

11）藤原公策，倉科空彰，高橋令治 (1967)：免疫血 清によるマウス Tyzzer 病感染防禦（第 20 回日 本細菌学会関東支部例会)。日本細菌学雑誌，22, 560 .

12) Fujiwara, K., Maejima, K., Takagaki, Y., Naiki, M., Tajima, Y. and Takahashi, R. (1964) : Multiplication des organismes de Tyzzer dans les tissus cérébraux de la souris expérimentalement infectée. Compt Rend. Soc. Biol., 158, 407-413.

13) Fujiwara, K., Takagaki, Y., Maejima, K., Kato, K., Naiki, M. and Tajima, Y. (1963): Tyzzer's disease in mice: Pathologic studies on experimentally infected animals. Japan. J. Exp. Med., 33, 183-202.

14) Fujiwara, K., Takagaki, Y., Naiki, M., Maejima, K. and Tajima, Y. (1964): Tyzzer's disease in mice. Effect of corticosteroids on the formation of liver lesions and the level of blood transaminases in experimentally infected animals. Japan. J. Exp. Med. 34, 5975.

15) Gard, S. (1944) : Bacillus piliformis infection in mice and its prevention. Acta path. micro- 
biol. scand., Supp. 54, 123-134.

16) Gomori, G. (1946) : A new histochemical test for glycogen and mucin. Amer. J. Clin. Path., 10, 177-179.

17) Gorer, P. A. (1947) : Some observations on the disease of mice: In : Care and Management of Laboratory Animals, 1st Ed., edited by Worden, A. N., pp. 160-167, Williams and Wilkins Co., Baltimore.

18) Gowen, J. W. and Schott, R. G. (1933) : Genetic predisposition to Bacillus piliformis infection among mice. J. Hyg., 33, 370-378.

19）橋本一，本多忠衛，杮沼義包，前野弘夫，三橋 進, 深井孝治, 小此木丘. (1961)：実験的チフス 症の研究一特にマウス対ゲルトネル腸炎菌の組 合せに扝いてーIXb) マウスに感染した S : enteritidis 強毒菌の臓器内分布について。 日本 細菌学雑誌， 16, 796-804.

20) Hauduroy, P. (1953) : In : Dictionnaire des Bactéries Pathogènes, p. 78. Masson and Co., Paris.

21) Kanazawa, K. and Imai, A. (1959) : Pure culture of the pathogenic agent of Tyzzer's disease of mice. Nature, 184, 1810-1813.

22）金子順一，藤田浩，松山繁夫，小島博，浅倉晴 弥，中村義治，児玉篤明（1960）：Tyzzer 氏病 の経験. 実験動物， 9, 148-156.

23) Maejima, K., Fujiwara. K., Takagaki. Y., Naiki, M., Kurashina, H. and Tajima, Y. (1965) : Dietetic effects on experimental Tyzzer's disease of mice. Japan. J. Exp. Med., $35,1-10$.

24) Naiki, M., Takagaki, Y. and Fujiwara, K. (1965) : Note on the change of transaminases in the liver and the significance of the transaminase ratio in experimenatal Tyzzer's disease of mice. Japan. J. Exp. Med., 35, 305309.

25) Right, F. L. Jackson, E. B. and Smadel, J. E. (1947) : Observations on Tyzzer's disease in mice. Amer. J. Path., 23, 627-635.

26) Saunders, L. Z. (1958) : Tyzzer's disease. J. Nat. Cancer Inst., 20, 893-898.

27) Takagaki. Y. and Fujiwara, K. (1968) : Bacteremia in experimental Tyzzer's disease of mice. Japan. J. Microbiol., 12, 129-143.

28) Takagaki, Y., Ito, M., Fujiwara, K., Maejima, K., Naiki, M. and Tajima, Y. (1964) : Effets d'antibiotiques et de sulfamides sur la maladie de Tyzzer chez la souris expérimentalement infectée. Compt. Rend. Soc. Biol., 158, 414-418.

29) Takagaki, Y., Ito, M., Naiki, M., Fujiwara, K., Okugi, M., Maejima, K. and Tajima, Y. (1966) : Experimental Tyzzer's disease in different species of laboratory animals. Japan. J. Exp. Med., 36, 519-534.

30）高垣善男, 岩田正之, 藤原公策, 田嶋嘉雄 (1961)： マゥスの Tyzzer 氏病に関する研究. I. 自然発 生例についての検索. 実験動物. 10,75-86.

31) Takagaki, Y., Naiki, M., Fujiwara, K. and Tajima, Y. (1962) : Maladie de Tyzzer expérimentale de la souris traitée avec la cortisone. Compt. Rend. Soc. Biol., 157, 438-441.

32）高垣善男，内貴正治，伊藤昌子，野口午郎，藤 原公策 (1967)：マウスの Corynebacterium 病求 よび Tyzzer 病污染のコーチゾン投与による検 出. 実験動物，16, 12-19.

33) Tuffery, A. A. (1956) : The laboratory mouse in Great Britain IV. Intercurrent infection (Tyzzer's disease). Vet. Rec., 68, 511-515.

34) Tyzzer, E. E. (1917) : A fatal disease of the Japanese waltzing mouse caused by a sporebearing bacillus (Bacillus piliformis N. sp.) J. Med. Res., 37, 307-338.

35) Wilson, G. S. and Miles, A. A. (1964) : In : Topley and Wilson's Principles of I3acteiology and Immunology 5th Ed., Vol. 1, pp. 530531, Edward Arnold Ltd., London. 


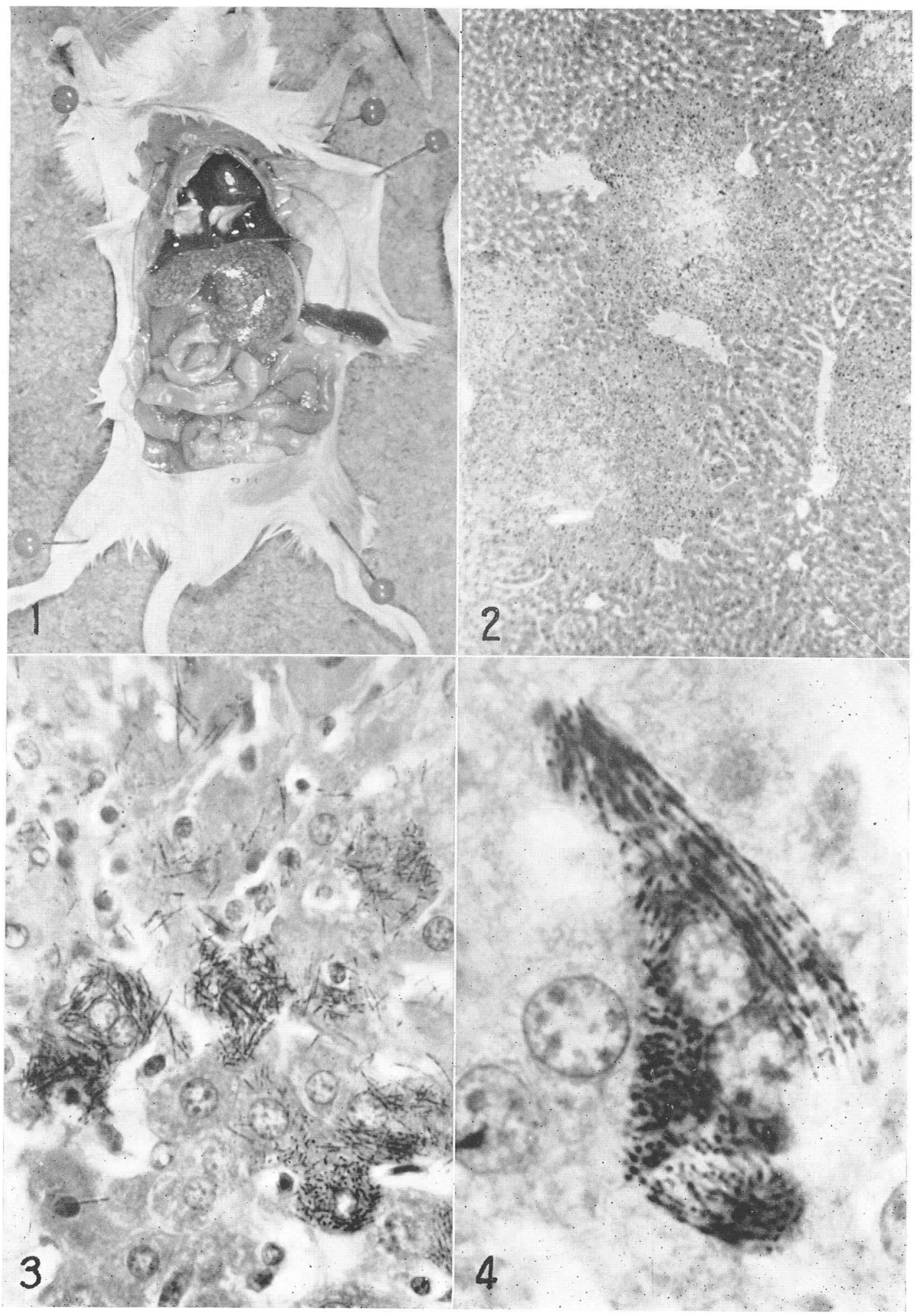




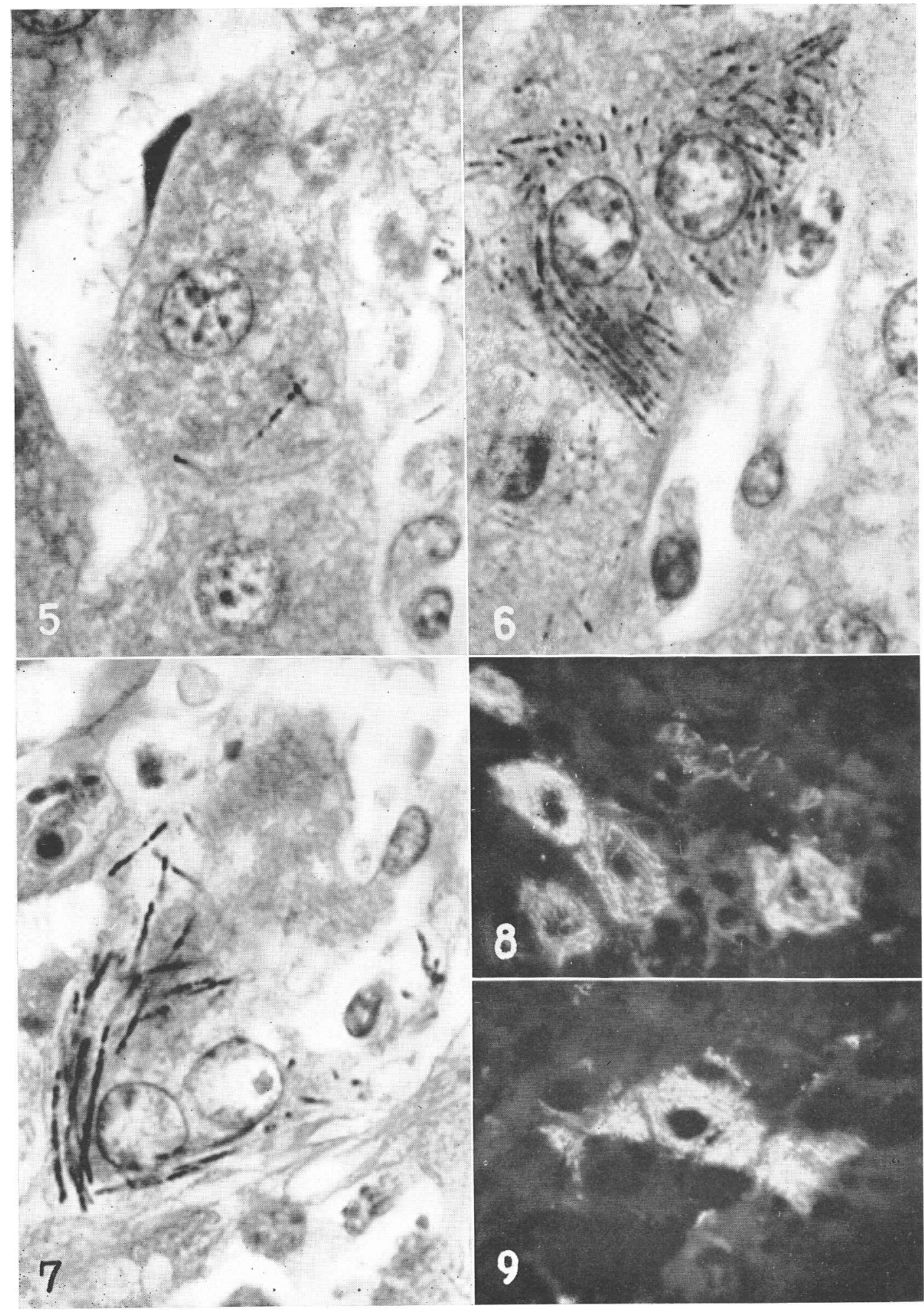




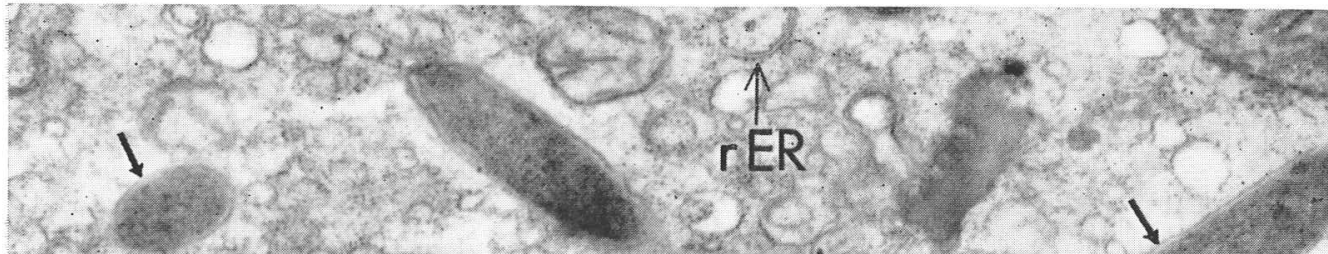

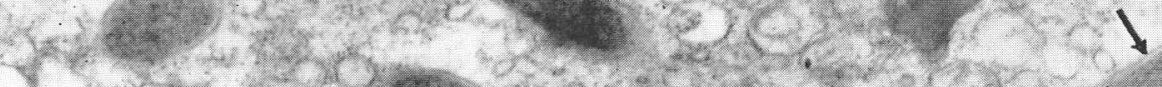

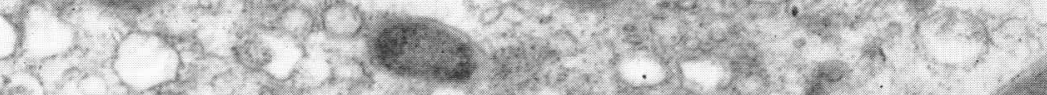

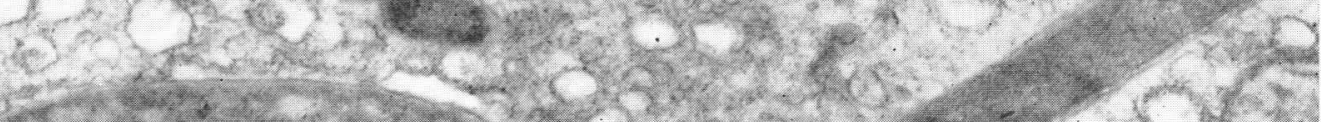

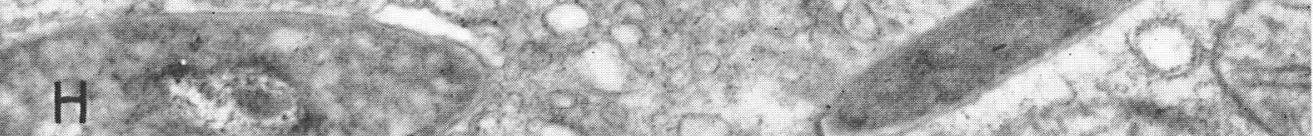

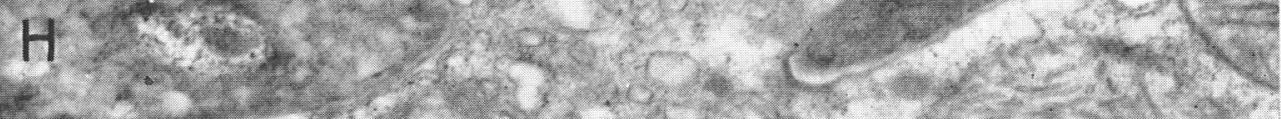

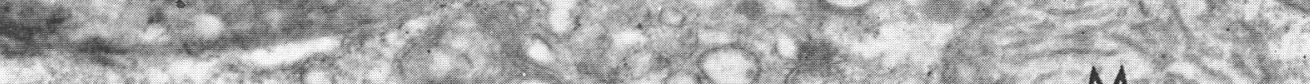

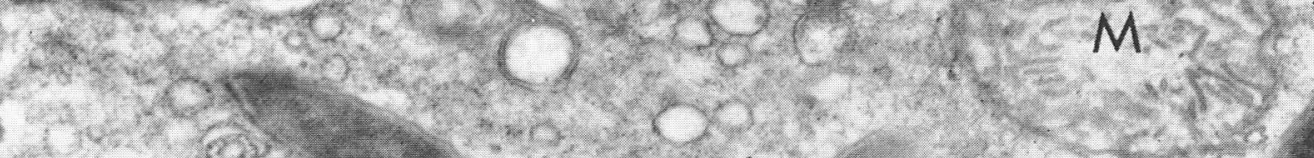

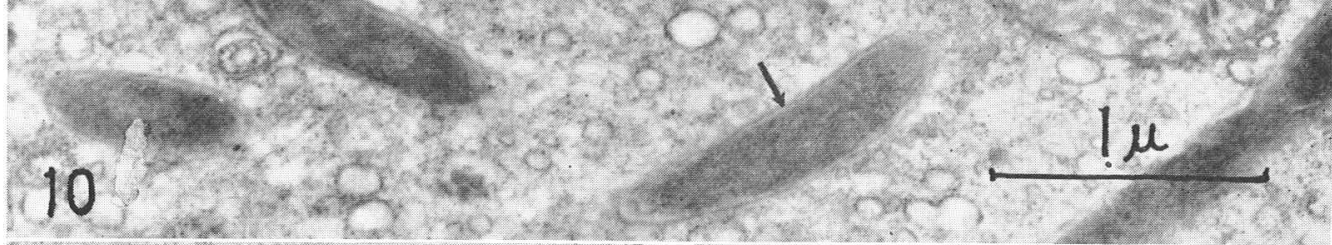

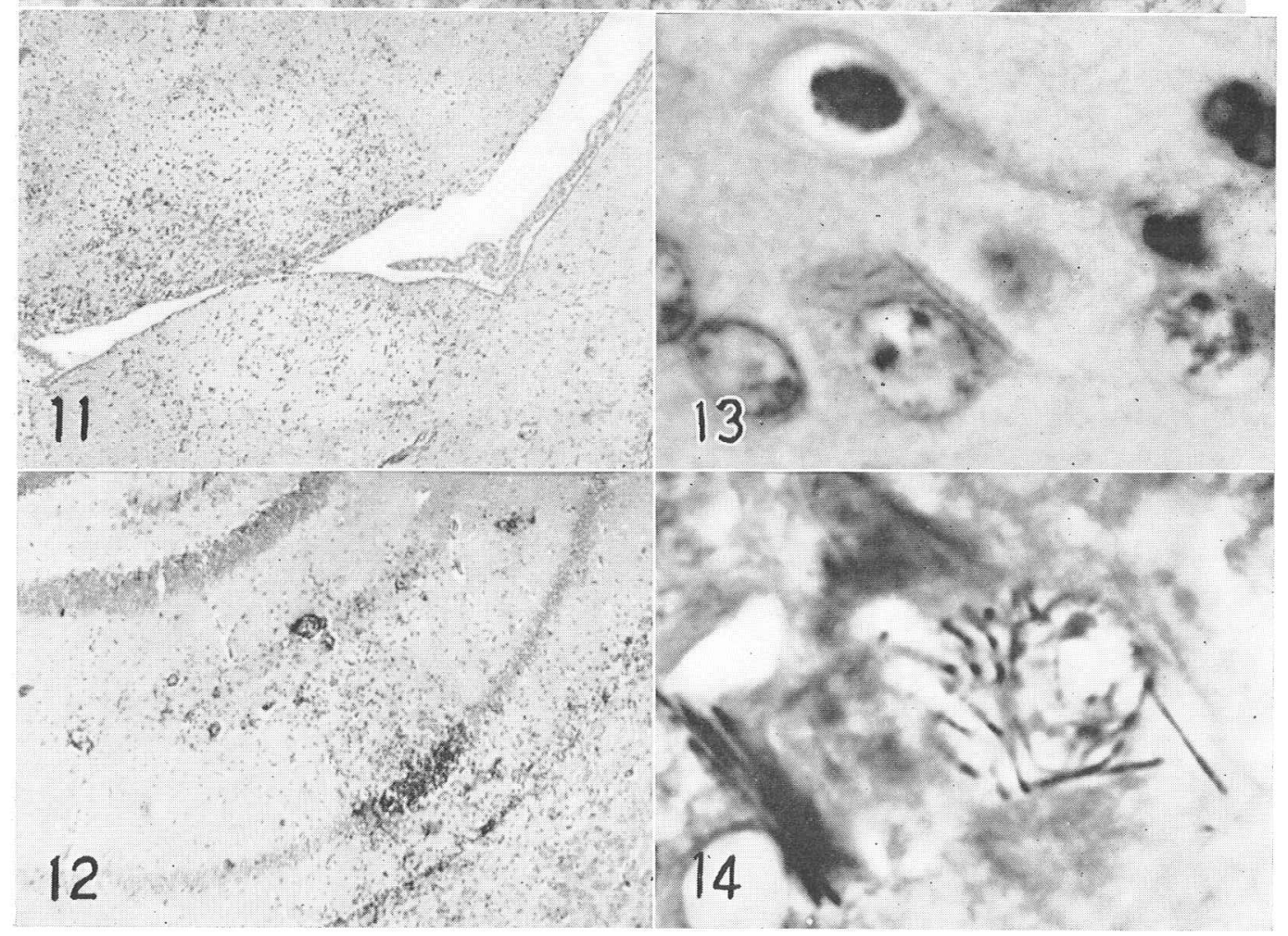




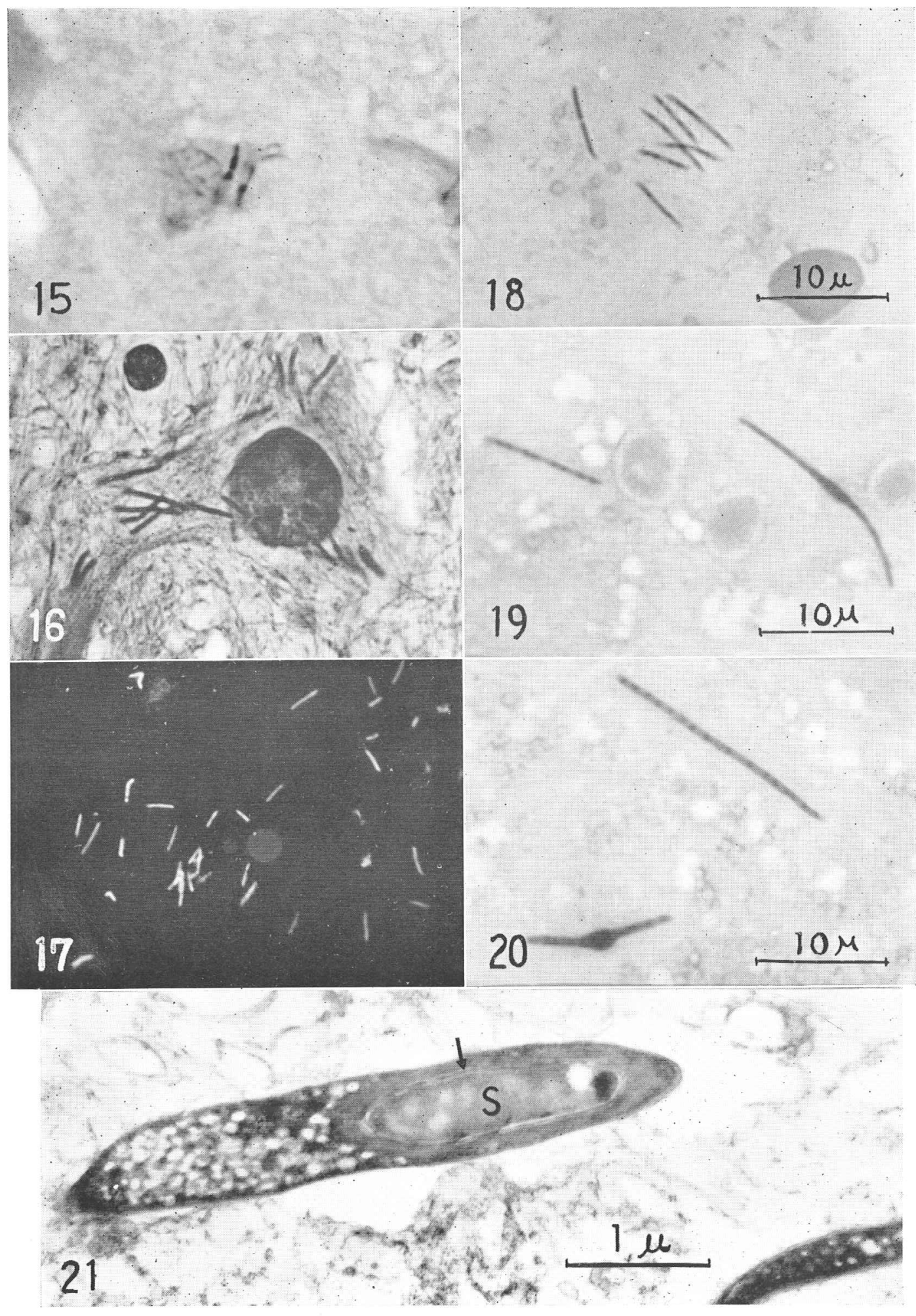


写真 1 10,21：SK 株(マウス 190 代継代感染肝) $1.6 \times 10^{6} / 0.1 \mathrm{mI}$ 静脈接種 3 日後殺・ ICR 5 週 マウス肝。

写真 11 20： SK 株 (感染脳) $1.3 \times 10^{3} / 0.02 \mathrm{ml}$ 脳内接種 3 日後殺 $\mathrm{ddY}$ マウス脸。

とくに記したものの他は Carnoy 固定標本。

写真 1 : 肉眼所見。

写真 2: 肝多発性巣状壊死。Haematoxylin-eosin (HE) 染色。

写真 $3:$ 壊死巣 (左上側) 周辺部肝細胞内菌体。Gomori 氏 methenamine - 硝酸銀一HE (GMS-HE) 染色。

写真 $4:$ 壊死巣から離れた部位の肝細胞内菌増殖像。GMS-HE 染色。

写真 5: 肝細胞感染初期像と類洞内皮。GMS-HE 染色。

写真 $6:$ 肝細胞内菌増殖像と星細胞。GMS-HE 染色。

写真 7 : 感染肝細胞の崩壊, 類洞への菌流出。GMS-HE 染色。

写真 8,9 : 螢光標識抗体を結合した肝細胞中の菌体。感染マウス肝アセトン 固定凍結切片を螢光 標識した抗感染マウス肝・ウサギ抗体で処置。

写真 10 : 感染肝細胞細胞質 の 超薄切片電顕像。 $\mathrm{rER}$; 粗面小胞体, $\mathrm{M}$; 糸粒体, 矢印; 菌体。 Osmium 酸固定。

写真 11 : 感染脳側脳室傍の軟化巣。HE 染色。

写真 12：感染脳 Ammon 角錐体状細胞層の崩壊，好中性多型核白血球浸潤。HE 染色。

写真 13 ：大脸皮質神経細胞感染初期像と変性。PAS-HE 染色。

写真 14：Ammon 角錐体状細胞内の菌増殖像。GMS-HE 染色。

写真 15：大脸皮質神経細胞内の芽胞型形成。GMS-HE 染色。

写真 16 ：視床側核神経節細胞内の菌增殖。Formalin 固定, Levaditi 鍍銀染色。

写真 17 : 抗感染マウス肝・ウサギ血清処置後, 螢光標識した抗ウサギ $\gamma$-globulin・ヤギ抗体を結 合した感染脳塗沫標本中の菌体。アセトン固定。

写真 18, 19, 20 : 感染脳塗沫標本の杆菌体と bulb 状膨大。Methanol 固定, Giemsa 染色。

写真 21 : 感染肝細胞細胞質内の芽胞型。Osmium 酸固定, 超薄切片電顕像。 